\title{
Muğla Bölgesi Orman Yangınları ve Yeniköy Kemerköy Termik Santrallerinin Risk Faktörleri
}

\author{
${ }^{* 1}$ Mahmut Suat Delibalta \\ ${ }^{* 1}$ Niğde Ömer Halisdemir Üniversitesi, Mühendislik Fakültesi Maden Mühendisliği Bölümü, Türkiye
}

\section{Özet}

Termik santraller; katı, sıvı ve gaz halindeki fosil yakıtların kimyasal enerjisinin, elektrik enerjisine dönüştürüldüğü tesislerdir. Türkiye'de elektrik enerjisi üretiminde yakıt olarak linyit, taşkömürü ve biokütle, ayrıca başta doğalgaz olmak üzere ithal kömür ve diğer petrol türevlerini kullanan 882 adet termik santral bulunmaktadır. Bu santrallerin büyük bir kısmı küçük kurulu güçte olup, doğalgaz ve kömür yakıtlı santraller ülkemiz elektrik enerji sistemi içerisinde önemli bir paya sahiptir. Ocak 2021 itibariyle termik santrallerin toplam kurulu gücü 20.323 MW büyüklüğünde ve ülkemiz toplam kurulu gücünün \%21'ini oluşturmaktadır. Kömüre dayalı santrallerin 52 adedi (11.336 MW) yerli kömür ve 15 adedi (8.987 MW) ise ithal kömürle çalışmaktadır. Kömür yakıtlı termik santraller genellikle linyit madeninin bulunduğu bölgelere yakın inşa edilmektedir. Ağustos 2021 Muğla bölgesi orman yangınları sırasında yanma tehlikesi atlatan Yeniköy ve Kemerköy santralleri de linyit sahalarına 20-25 km uzaklıkta orman havzasında deniz kıyısına yakın inşa edilmiştir. Söz konusu termik santrallerin stok sahasında bulunan fuel-oil, hidrojen tankı ve yaklaşık 40 50 bin ton kömürün kontrolsüz bir şekilde yanması halinde açığa çıkacak ısı ve zararlı gazların sağlık, güvenlik ve çevresel pek çok risklere yol açabileceği görülmüştür. Bu maksatla yapılan araştırmada; Muğla bölgesi orman yangınları ve doğal afetlerde termik santrallerin risk faktörleri farklı boyutlarıyla incelenerek, çözüm önerileri sunulmuştur.

Anahtar Kelimeler: Muğla, doğal afetler, orman, yangın, termik santral.

\section{Risk Factors of Forest Fires in the Muğla Region and Yeniköy Kemerköy Thermal Power Plants}

\begin{abstract}
Thermal power plants are facilities where the chemical energy of solid, liquid and gaseous fossil fuels is converted into electrical energy. There are 882 thermal power plants in Turkey that use lignite, coal and biomass as fuel in the production of electrical energy, as well as imported coal and other oil derivatives, mainly natural gas. Most of these power plants have a small installed capacity, natural gas and coal-fired power plants occupy a significant share in the electrical energy system of our country. As of January 2021, the total installed capacity of thermal power plants is $20.323 \mathrm{MW}$ and accounts for $21 \%$ of the total installed capacity of our country. 52 $(11.336 \mathrm{MW})$ of coal-based power plants are powered by domestic coal and $15(8.987 \mathrm{MW})$ are powered by imported coal. Coal-fired power plants are usually built near the areas where the lignite mine is located. In August 2021, the Yeniköy and Kemerköy power plants, which survived the danger of burning during the forest fires of the Muğla region, were also built near the seashore in the forest basin 20-25 km away from the lignite fields. It has been seen that if the fuel-oil, hydrogen tank and about 40 50 thousand tons of coal in the inventory area of the thermal power plants in question are burned uncontrollably, the heat and harmful gases that will be released can lead to many health, safety and environmental risks. In the research conducted for this purpose, the risk factors of thermal power plants in forest fires and natural disasters in the Muğla region have been examined with different dimensions and solution suggestions have been presented.
\end{abstract}

Keywords: Muğla, natural disasters, forest, fire, thermal power plant.

\footnotetext{
${ }^{*}$ Corresponding author: Address: Faculty of Engineering, Department of Mining Engineering Niğde Ömer Halisdemir University, 51240, Niğde TURKEY. E-mail address: msdelibalta@ohu.edu.tr, Phone: +903882252387.
} 


\section{Giriş}

Türkiye, bugün dünyada en fazla kömür üreten 11 'inci ülke ve 2013 y1lından bu yana Moğolistan ve Pakistan'dan sonra kömür üretimini en çok arttıran 3'üncü ülke konumundadır. 2013-2019 döneminde kömür üretimi \%44 oranında artarak 60 milyon ton seviyesinden 87 milyon ton düzeyine yükselmiştir. Dünyada daha yüksek üretim artışları sadece Hindistan (148 milyon ton) ve ihracatçı ülkeler olan Endonezya (135 milyon ton) ile Rusya'da (84 milyon ton) gerçekleşmiştir. Aynı dönemde, dünya toplam kömür üretimi \%1,5 oranında azalmıştır. Türkiye'nin kömür ithalatı 2013 yılı sonrası \%43 oranında artış göstermiş ve 2019 yılında 38 milyon ton düzeyine yükselmiştir. Dünya kömür ithalatının \%2,7'sini yapan ülkemiz 7'nci sırada bulunmaktadır.

Türkiye'de 2019 yılı arz edilen toplam 126 milyon ton kömürün \%65'i elektrik üretimi amaciyla termik santrallerde, \%24'ü sanayide ve kok firınlarında, \%11'i ise ısınma amaciyla konutlarda tüketilmiştir. Ocak 2021 itibarıyla kömüre dayalı elektrik santrallerin toplam kurulu gücü 20.323 MW büyüklüğünde ve ülkemiz toplam kurulu gücünün \%21'ini oluşturmaktadır. Kömüre dayalı santrallerin 52 adedi (11.336 MW) yerli kömür ve 15 adedi (8.987 MW) ise ithal kömürle çalışmaktadır $[1,2]$. Ülkemiz elektrik üretiminde kullanılan yerli yakıtlar, ağırlıklı olarak düşük kalorifik ve linyit olarak ifade edilen kömürlerdir.

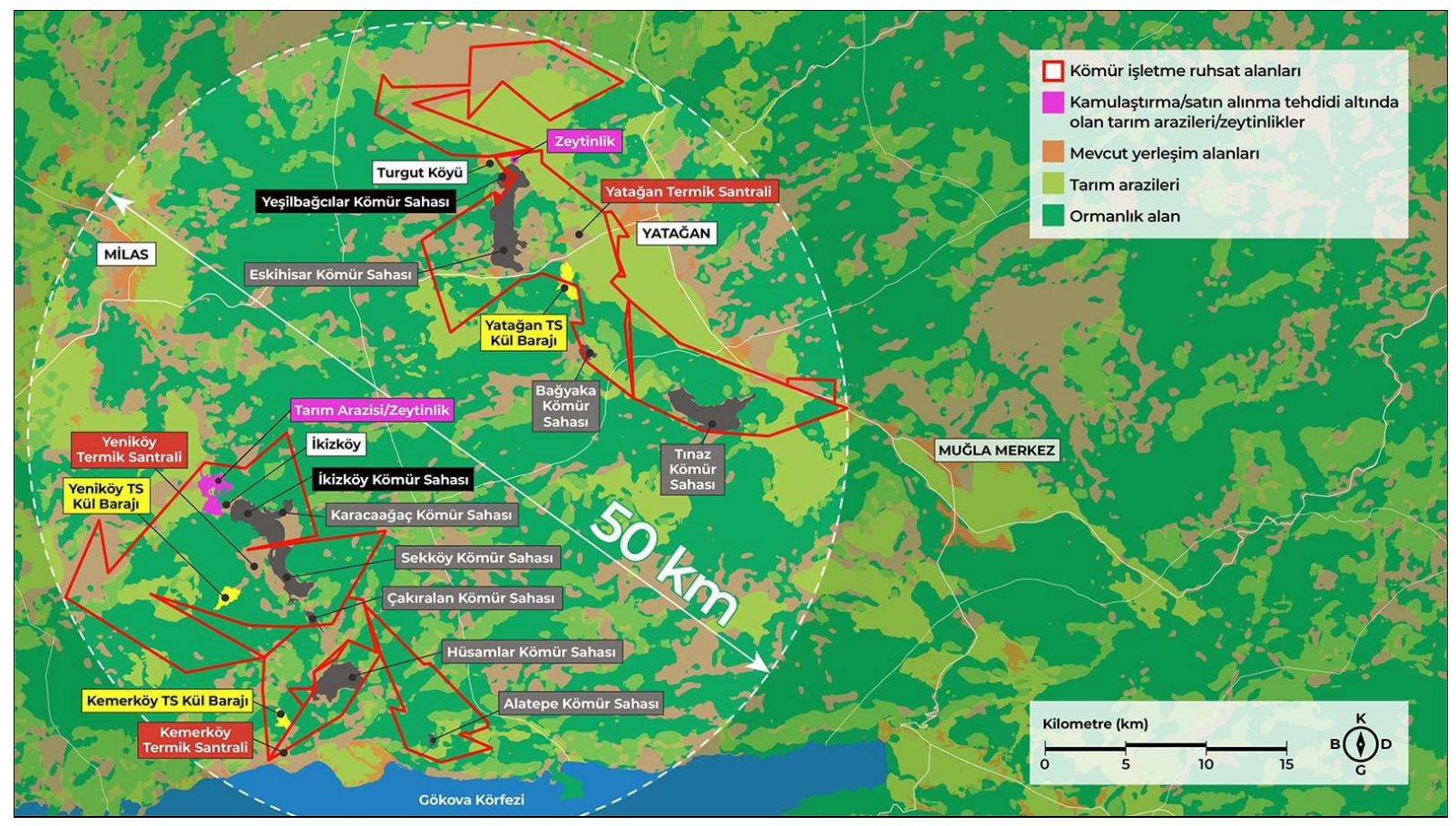

Şekil 1. Yată̆an, Yeniköy, Kemerköy termik santrallerinin coğrafi konumu [3]

Büyük kapasiteli termik santrallerin Türkiye'de yaygınlaşması 1973 yılından itibaren başlamış, 2000 yılına kadar yerli kömüre dayalı termik santraller peş peşe kurulmuştur. Bunlar arasında; Seyitömer, Tunçbilek B, Soma B, Yatağan, Yeniköy, Kemerköy (Şekil 1), Afşin-Elbistan A, Çayırhan, Kangal ve Orhaneli santralleri bulunmaktadır. Ayrıca, 2000 ile 2005 yılları arasında yerli 
kömüre dayalı herhangi bir termik santral işletmeye alınmamıştır. Beş yıllık bir aradan sonra, 2005-2006 yıllarında Afşin-Elbistan B Santrali ile Çan Santrali devreye girmiştir. Son yıllarda, çok sayıda teşvik düzenlemesine karşın yerli kömüre dayalı termik santral yatırımları konusunda önemli bir gelişme sağlanamamıştır. 2006 yılı sonrasında işletmeye giren linyite dayalı santral kapasitesi yaklaşık 2.000 MW düzeyindedir. Bunlar arasında; Aksa Göynük Santrali, Enerjisa Tufanbeyli Santrali, ODAŞ Çanakkale Çan 2 Santrali ve Soma Kolin Santrali bulunmaktadır.

Bununla birlikte, tarihsel gelişim sürecindeki tüketim artışları kömürün doğal ve toplumsal çevreye olan olumsuz etkilerini tüm dünyada ve ülkemizde iyice gözle görülür hale getirmiştir. Küresel ısınmanın bir numaralı faili olan $\mathrm{CO}_{2}$ emisyonlarında kömürün payı hızla artarak 2000 yılındaki \%38 seviyesinden 2013 yılında \%46 düzeyine kadar yükselmiş, bu süreçte kömür en fazla tartış1lan fosil enerji kaynağı haline gelmiştir. Ağustos 2021 Muğla bölgesi orman yangınları sırasında yanma tehlikesi atlatan Yeniköy Kemerköy santralleri de ülkemiz kamuoyunda gündeme gelmiştir. Söz konusu termik santrallerin stok sahasında bulunan fuel-oil, hidrojen tank1 ve yaklaşık 40 50 bin ton kömürün kontrolsüz bir şekilde yanması halinde açığa çıkacak ısı ve zararlı gazların sağlık, güvenlik ve çevresel pek çok risklere yol açabileceği görülmüştür. Bu maksatla yapılan araştırmada; Muğla bölgesi orman yangınları ve doğal afetlerde termik santrallerin risk faktörleri farklı boyutlarıyla incelenerek, çözüm önerileri sunulmuştur.

\section{Materyal ve Metot}

Yeniköy Kemerköy termik santralleri, Muğla ili Milas ilçesinde yerli linyit kömürü kullanarak elektrik üretmek amacıyla, sırasıyla 1987 ve 1995 yıllarında faaliyete geçmiştir. Yeniköy Kemerköy santralleri, 23.12.2014 tarihinde Limak-IC İçtaş eşit ortaklığı tarafindan özelleştirme yoluyla devralınmıştır. Kömür üretim faaliyetleri İR:10413 No'lu ruhsat sahasında yürütülmekte olup, maden sahalarından temin edilen linyit kömürü elektrik üretimi için tüketilmektedir. 2015 yılında toplam 9,3 milyon ton kömür üretilerek santrallere sevk edilmiştir.

Yeniköy termik santrali her biri 210 MW gücünde 2 adet üniteden, Kemerköy termik santrali ise 2020 yılı rehabilitasyon çalışmaları kapsamında gerekli revizyonlar yapılarak, 1 adet 232,604 MWe ve 2 adet 210 MWe gücünde 3 üniteden oluşmaktadır. 2015 yılı Kemerköy için kapasite kullanım oranı \%76, brüt üretim $4.187 \mathrm{GWh}$, Yeniköy için \%78 ve $2.864 \mathrm{GWh}$ olarak gerçekleşmiştir. Yeniköy ve Kemerköy termik santrallerinde satışa esas 2020 y1lı net enerji üretim değerleri sırasıyla 2,831 ve 3,101 milyar kWh olmuştur [4]. Tesislerde, emre amadelik ve elektrik üretimini artırmaya yönelik yatırımlar devam etmektedir. Bildiri kapsamında, Muğla bölgesi orman yangınları etkisinde termik santrallerin risk faktörleri istatistiksel ve görsel verilerle irdelenmiştir.

\section{Bulgular}

Yirminci yüzyılın başlarında dünya enerji ihtiyacının yaklaşık \%60'ını karşılayan kömür, önce petrolün sonra doğalgazın rekabetiyle 60'lı yılların ortalarından itibaren lider konumunu kaybetmiş, yüzyılın sonunda ise küresel enerji tüketimi içindeki payı \%22 seviyelerine kadar gerilemiştir [1]. 
Sanayi devriminin başrol oyuncularından olan kömür, günümüzde en çok tartışılan fosil yakıt haline gelmiştir. Kömürün yakılmasından kaynaklanan sera gazlarının küresel ısınmayı arttırması ve kirleticilerin çevre, doğal yaşam, insan-canlı sağlığı üzerindeki olumsuz etkileri; günümüzde kömür santrallerine olan tepkileri arttırmaktadır. Fakat coğrafi olarak yaygın olması ve bol bulunması, ucuz (ekonomik) olması nedeniyle kömür, gelişmekte olan ülkeler için halen önemli bir enerji kaynağı olmaya devam etmektedir.

\subsection{Kömür Yakıtlı Termik Santrallerde İşleyiş}

Kömüre dayalı termik santrallerdeki ana işlem kömürde var olan kimyasal enerjinin elektrik enerjisine dönüştürülmesidir. Bu dönüşüm, esas itibarı ile büyük miktardaki kömürün kazan adı verilen yanma odasında yakılması ile elde edilen 1sı ile bir dizi arıtma işlemi ile saflaştırılan suyun yüksek basınç ve sıcaklıkta buharlaştırılması ve bu buharın türbinde mekanik enerjiye, jeneratörde de elektrik enerjisine dönüştürülmesi ile gerçekleştirilmektedir (Şekil 2).

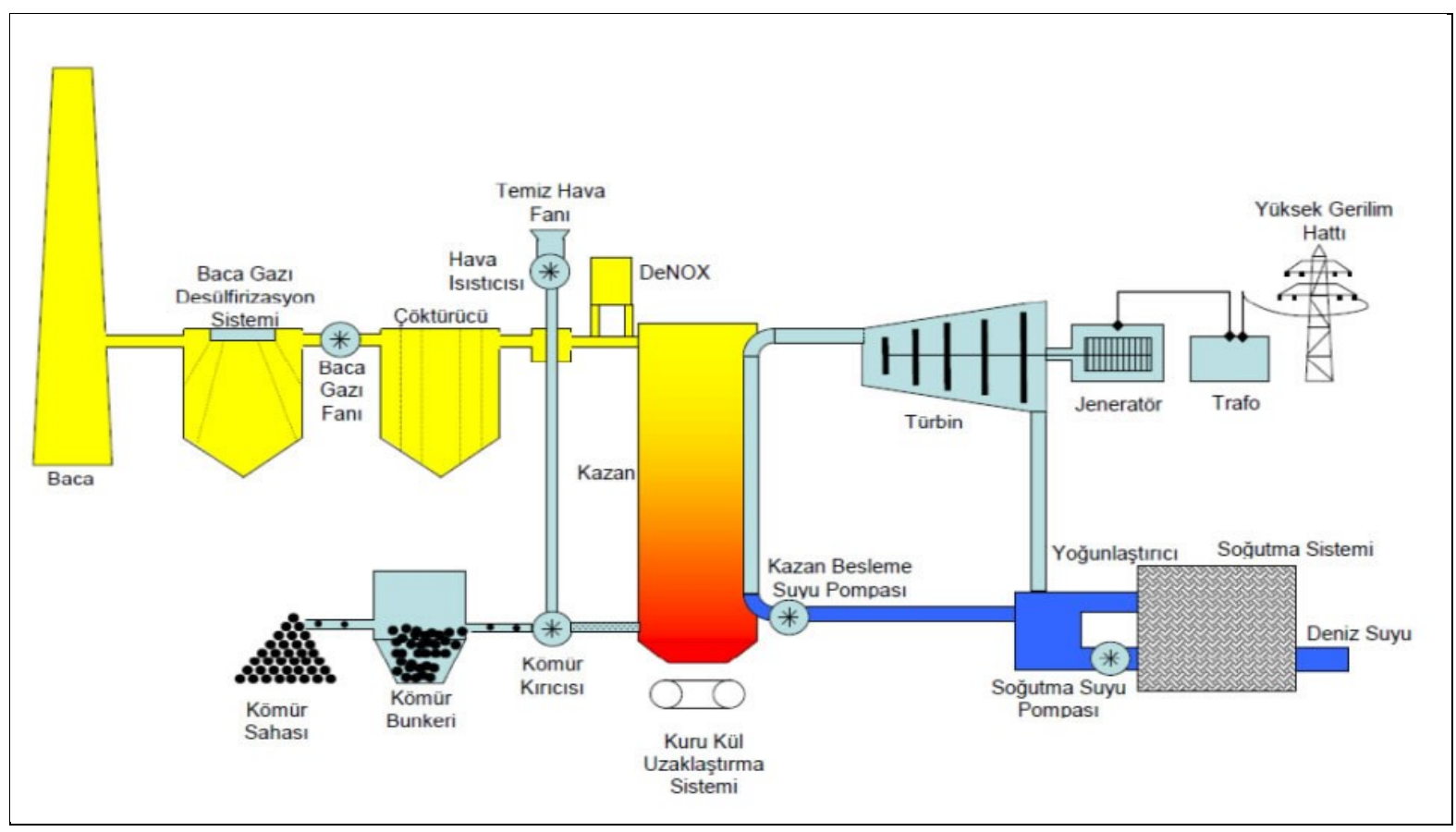

Şekil 2. Tipik bir kömür yakıtlı termik santral işleyiş şeması [5]

Günümüzde geleneksel kömür yakıtlı enerji üretim sistemi kazan tipine bağlı olarak; pulvarize ya da akışkan yataklı kazan teknolojileridir. Entegre Gazlaştırma Kombine Çevrim (EGKÇ) teknolojisi ise henüz denenme ve araştırma/geliştirme aşamasındadır.

Pulvarize kömür yakma sisteminde; maden ocağından 0-1000 mm büyüklükte çıkan kömürler, döner kırıcıdan geçirilerek, boyutları önce 0-300 mm, ardından da 0-30 mm'ye düşürülür. Buradan sıcak gaz kanalına dökülerek, neminin minimum seviyeye indirilmesi sağlanır. Fanlı tip değirmenlere gelerek öğütülür ve toz haline getirilir. Son aşamada kömür kanalları ile buhar kazanlarına püskürtülür. Böylece yakıtın kimyasal enerjisini, ısı enerjisi şeklinde açığa çıkaran 
yanma işlemi gerçekleşir. Yanma sonucu oluşan yaklaşık $1400{ }^{\circ} \mathrm{C}$ sıcaklıktaki gazların 1sı enerjisi, kazanda sirküle edilen suyun buhar çevrimine aktarılır. Buhar kazanından elde edilen yüksek basınç ve sıcaklıktaki buhar, konvansiyonel bir buhar türbininden geçirilerek türbine akuple jeneratörün elektrik üretmesini sağlar [5,6]. Türkiye'deki kömür yakıtlı santrallerin çoğunluğu düşük kalorifik değere sahip linyite dayalı olduklarından, maden sahasının hemen yanında kurulmuşlardır.

\subsection{Termik Santrallerde Yangın Tehlikesi Olan Başlıca Tesisler}

Kömür yakıtlı termik santrallerde yangın tehlikesi arz eden başlıca tesisler şunlardır:

1. Kömür taşıma bantları

2. Kömür depolama (stok) alanları

3. Kömür yakma tesisleri

3.1. Kömür hazırlama

3.2. Kömür yakma

4. Elektrik üretim tesisleri

4.1. Türbin jeneratörler

4.2. Kablo kanalları

4.3. Trafolar

4.4. Kontrol odas 1

5. Yardımcı işletmeler

Çeşitli ülkelerde kömür yakıtlı termik santrallerde meydana gelen 31 adet yangına ilişkin istatistik verilere (bkz. Şekil 3, 4) göre, nedenler arasında ilk iki sırada kazan patlamaları ve yağlama sistemindeki arızalar yer almaktadır. Tespit edilen söz konusu verilerin analizi, bu hususta alınacak önlemlere yol göstermesi bakımından çok önemlidir.

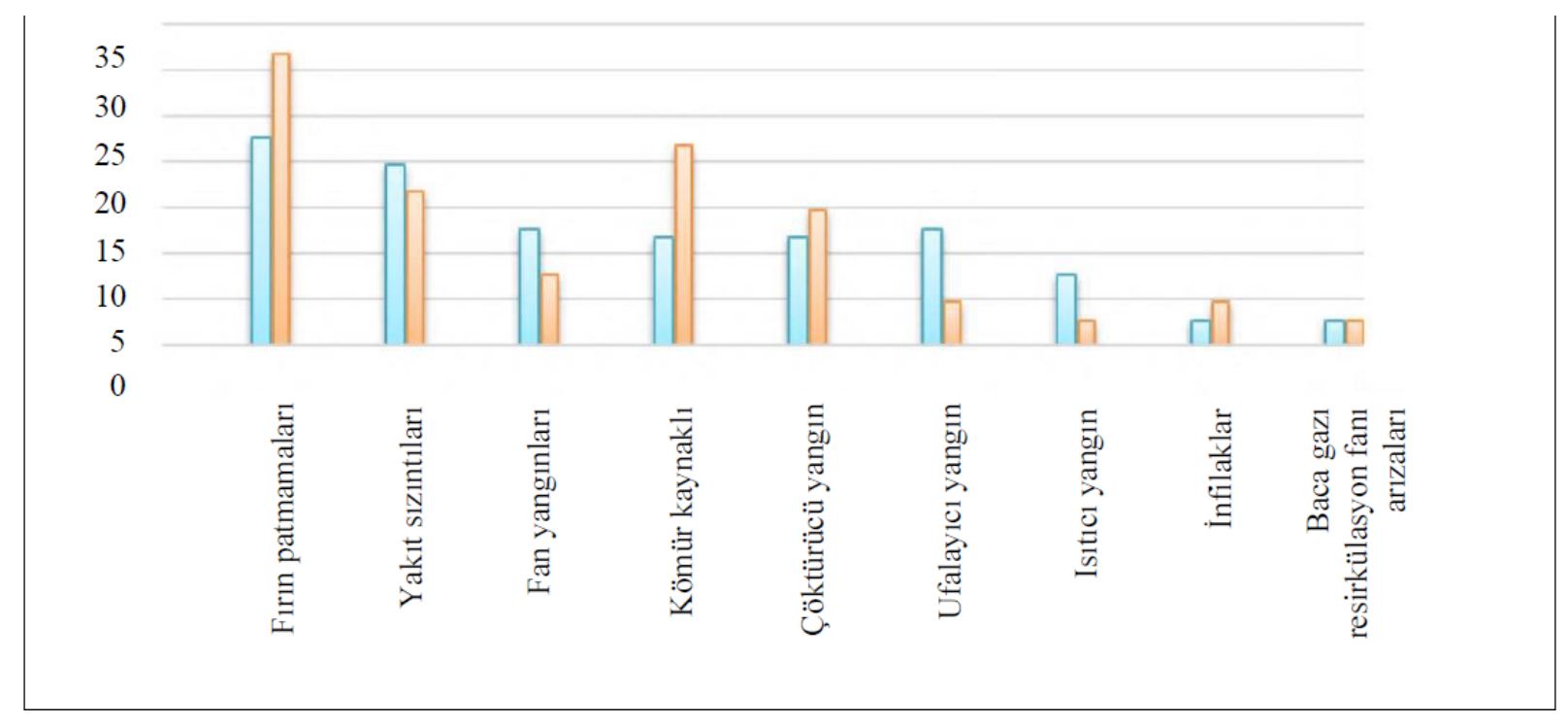

Şekil 3. Termik santrallerde yangınların oluş yeri ve zarar yüzdesi [7] 


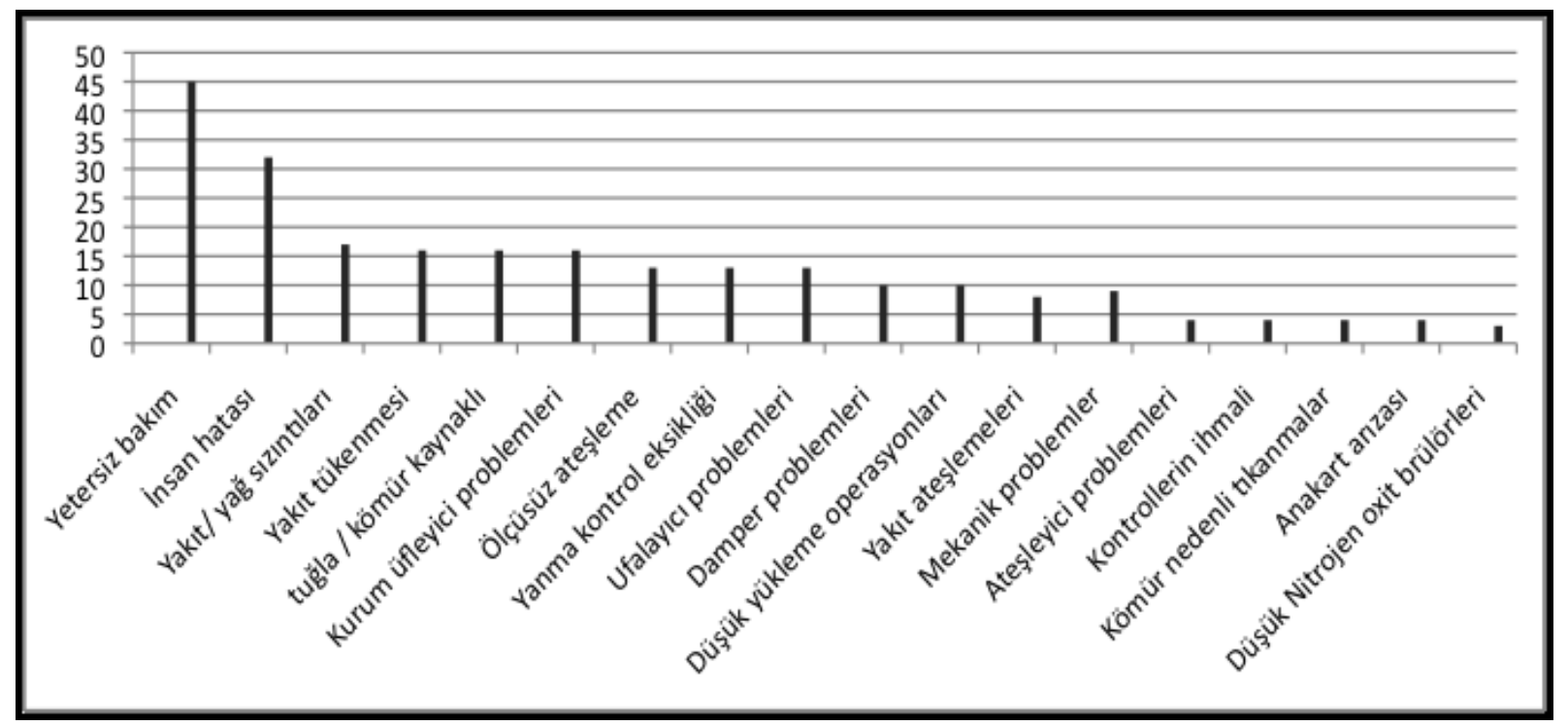

Şekil 4. Termik santral yangınlarındaki kök nedenler ve \% değerleri [7]

Türkiye'de orman sahalarına yakın inşa edilen termik santrallere ayrı bir özen gösterilmesi gerekmektedir. Özellikle bu tür santrallere, orman yangınlarının sirayet etmesini önleyecek (açık arazi koridoru, yangın duvarları, toprak örtü vs. gibi) önlemler alınmalıdır. Bunun nedeni; santrallerin yanan ormanlardan daha değerli olması değil, olası afet sırasında ekiplerin yangın yerine santral ile mücadele etmelerini engellemektir. Yangınların santrallere vereceği zararlar kısmen bakım-onarım faaliyetleri ile giderilebilir, ancak yanan orman ve doğal yaşamın tekrar eski haline dönmesi onlarca yıl sürmektedir [8]. Ayrıca; termik santral tesis yangınlarına karşı alınacak önlemler için, 6331 sayılı İş Sağlığı ve Güvenliği Yasası kapsamında "Binaların Yangından Korunma Yönetmeliği" ile uluslararası kabul gören "National Fire Protection Codes" ve "FM Global Data Sheets" uygulamaları referans kaynaklar olarak izlenebilir.

\section{Sonuçlar ve Tartışma}

Sanayi devriminin başrol oyuncularından olan kömür, günümüzde en çok tartış1lan fosil enerji kaynağı haline gelmiştir. Kömürün yakılmasından kaynaklanan sera gazlarının küresel ısınmayı arttırması ve kirleticilerin çevre, doğal yaşam, insan-canlı sağlı̆̆ üzerindeki olumsuz etkileri; kömür santrallerine olan tepkileri arttırmaktadır. Fakat yerkürede coğrafi olarak yaygın ve bol bulunması, ucuz (ekonomik) olması nedeniyle kömür, gelişmekte olan ülkeler için halen önemli bir enerji kaynăğ olmaya devam etmektedir.

Türkiye'de 2019 yılı arz edilen toplam 126 milyon ton kömürün \%65'i elektrik üretimi amaciyla termik santrallerde, \%24'ü sanayide ve kok firınlarında, \%11'i ise 1sınma amaciyla konutlarda tüketilmiştir. Ocak 2021 itibarıyla kömüre dayalı elektrik santrallerin toplam kurulu gücü 20.323 MW büyüklüğünde ve ülkemiz toplam kurulu gücünün \%21'ini oluşturmaktadır. Kömüre dayalı santrallerin 52 adedi (11.336 MW) yerli kömür ve 15 adedi (8.987 MW) ise ithal kömürle çalışmaktadır. 
Yeniköy Kemerköy termik santralleri, Muğla ili Milas ilçesinde yerli linyit kömürü kullanarak elektrik üretmek amacıyla, sırasıyla 1987 ve 1995 yıllarında faaliyete geçmiştir. Yeniköy termik santrali, her biri $210 \mathrm{MW}$ gücünde 2 adet üniteden oluşmaktadır. Kemerköy termik santrali ise 2020 y1lı rehabilitasyon çalışmaları kapsamında gerekli revizyonlar yapılarak, 1 adet 232,604 MWe ve 2 adet 210 MWe gücünde 3 üniteden oluşmaktadır.

Ağustos 2021 Muğla bölgesi orman yangınları sırasında yanma tehlikesi atlatan Yeniköy Kemerköy santralleri, afet riski bakımından ülkemiz kamuoyunda gündeme gelmiştir (Şekil 5, 6). Söz konusu termik santrallerin stok sahasında bulunan fuel-oil, hidrojen tank1 ve yaklaşık 40 50 bin ton kömürün kontrolsüz bir şekilde yanması son anda engellenerek, açığa çıkacak 1sı ve zararlı gazların yaratacağı sağlı, güvenlik ve çevresel pek çok risk önlenmiştir.

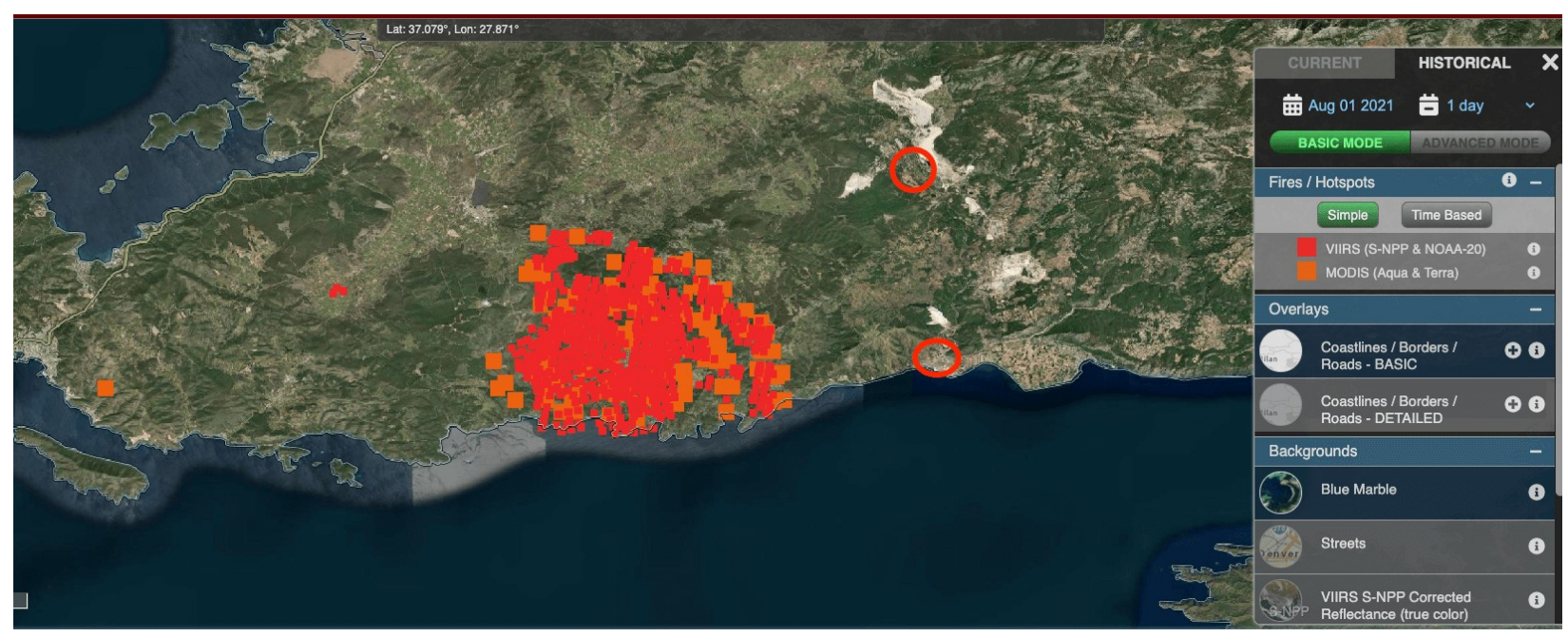

Şekil 5. Muğla-Milas orman yangınları başlama ve Yeniköy Kemerköy termik santralleri [3]

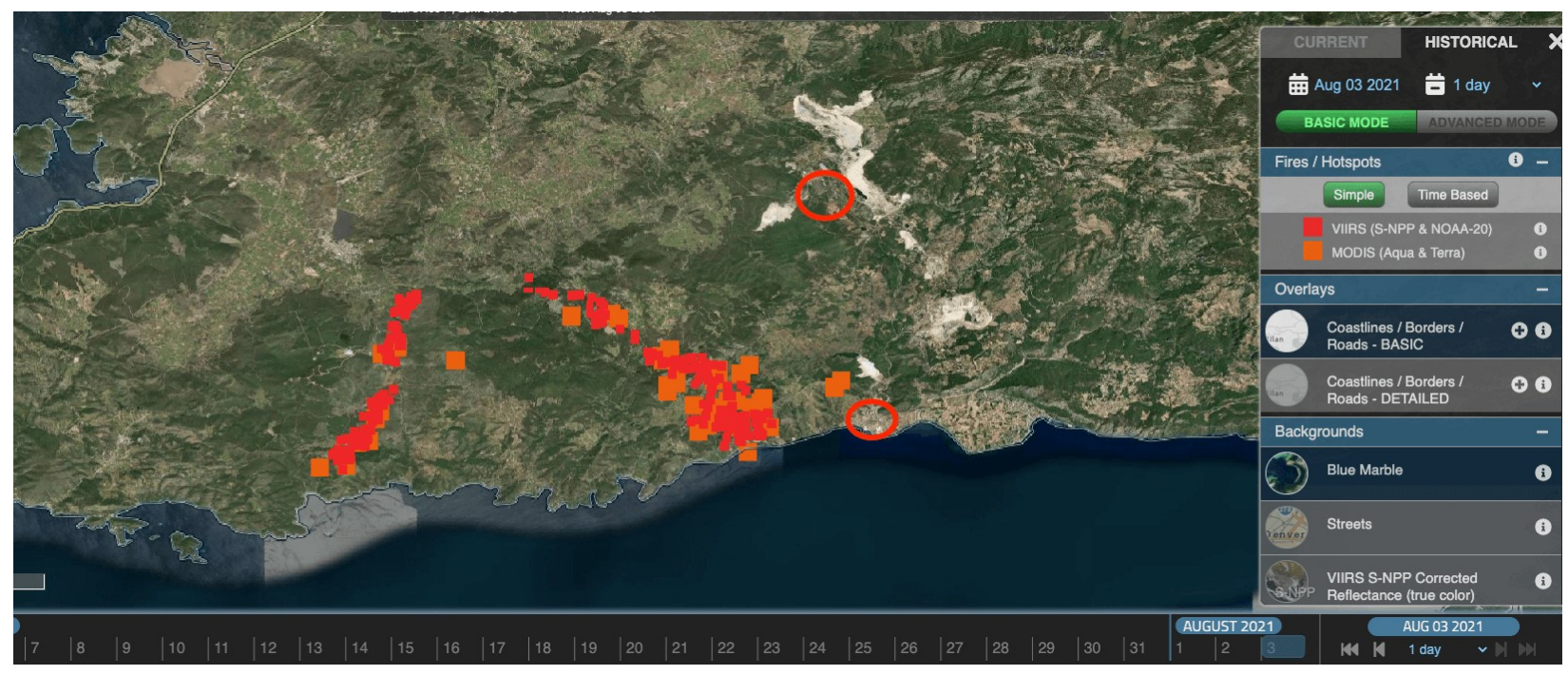

Şekil 6. Muğla-Milas orman yangınları ilerlemesi ve Yeniköy Kemerköy termik santralleri [3] 
Orman yangınları doğal afetlerdir ve önlenmesi için kurumlararası eşgüdüm ve işbirliği gerektirmektedir. Türkiye'de 2021 yılı Temmuz-Ağustos aylarında yaşanan büyük orman yangınlarının (Muğla 66.252 hektar) esas önemi doğaya verdiği zararlardır, elektrik enerji sistemine verebileceği hasar bunun yanında çok daha küçük (ülkemiz kurulu gücündeki pay1 \%1) ölçektedir. Ayrıca; bahse konu santraller ülkemiz deprem tehlike haritasına göre, en riskli (I. Derece / Yüksek Tehlike) bölgesi sınırlarında bulunmaktadır [9]. Bu tür afetlerin ülkemizde tekrar yaşanmaması için tüm yetkililer; yangın, deprem ve doğal afetler yönetimi hususunda mutlaka sürdürülebilir önlem ve tedbirleri almakla yükümlüdürler.

\section{Kaynaklar}

[1] Tamzok, N. Dünya'da ve Türkiye'de kömür politikaları. Sır V., editör. TMMOB Maden Mühendisleri Odası - Kömür ve Enerji Çalıştayı Bildiriler Kitabı, 20 Şubat 2021, s.5-22.

[2] Delibalta, M.S. Türkiye'de fosil enerji kaynakları ve yeni nesil termik santrallerin önemi, Uluslararas1 Enerji, Ekonomi ve Güvenlik Kongresi-ENSCON'18, Kozyatağ1/ İstanbulTürkiye, ISBN: 978-605-81728-2-1, s.22-34, 21-22 Nisan, 2018.

[3] Acanerler, A. Büyüteç: Yangınlar termik santralları nasıl etkiler? Teyit, Ağustos 2021, s.1-8.

[4] http://www.limak.com.tr/sektorler/enerji/enerji-uretimi/isletmedeki-termik-santraller/yenikoykemerkoy-termik-santralleri (Erişim tarihi: 14.09.2021).

[5] TMMOB Terme Termik Santral Raporu, Türk Mühendis ve Mimar Odaları Birliği, ISBN 978605-01-0678-7, s.24, Ankara: Ocak 2015.

[6] Aytaç, O. Kömür yakıtlı santrallar, çevresel etkileri, ülkemizdeki durum, geleceğe bakış. Sır V., editör. TMMOB Maden Mühendisleri Odası - Kömür ve Enerji Çalıştayı Bildiriler Kitabı, 20 Şubat 2021, s.97-137.

[7] Kozacı, C. Kömür yakıtlı termik santrallerde yangın tehlike kaynakları, riskler ve kontrol önlemleri, Türkiye'de Termik Santraller 2017, TMMOB, Makina Mühendisleri Odas1Ankara, 2017, s.303-319.

[8] Damar, N.B. Orman yangınları ve termik santraller, BİA Haber Merkezi, s.8, İstanbul, 2021.

[9] AFAD 2018 Türkiye Deprem Tehlike Haritası, Afet ve Acil Durum Yönetimi Başkanlığı, Deprem Dairesi Başkanlığı (https://deprem.afad.gov.tr/), Çankaya/Ankara. 